Tatiana Shparaga, Candidate of Science (Geography), Senior Lecturer, Taras Shevchenko Kyiv National University, 64, Volodymyrska str., Kyiv, 01601, Ukraine,

ORCID: 0000-0003-2713-1409

Researcher ID https://publons.com/researcher/3456044/tetiana-shparaga/

\title{
THE USE OF GREAT BRITAIN EXPERIENCE IN ORGANIZING AND PROMOTING TOURISM IN THE BOTANIC GARDENS OF UKRAINE
}

The key experience of Great Britain in organizing and promoting tourism in various botanic gardens is explored. The main functional responsibilities of the employees in the botanic gardens of Great Britain are systemized. The different partner programs for conservation and development of botanic gardens in Great Britain are revealed. The directions of Great Britain experience usage in promoting tourist activity in botanic gardens of Ukraine are substantiated. The mechanisms of increasing attendance of parks and gardens as tourist destinations of Ukraine are proposed.

Keywords: Great Britain, Ukraine, botanic gardens, promoting experiences, functional responsibilities.

Relevance of research topic. The Great Britain has extensive experience in organizing and promoting tourism in various botanic gardens: royal, university, family, monastery, castle and others. It is noteworthy that these are the botanic gardens that offer unique opportunities for meeting the needs for recreation, and therefore for tourism development. Promoting a botanic garden in the tourist market means much more than just attracting more visitors. It is primarily about attracting assistance from people of various professions and interests who are working hard to popularize botanic garden destinations among potential visitors and to enhance tourism development in their territory.

Formulation of the problem. The main problem of this study consists in investigations of theoretical substantiation and practical experience of Great Britain in organizing and promoting tourism in various botanic gardens as well as in implementation of the results of this investigations on Ukrainian botanical garden's territory.

Analysis of recent researches and publications. The investigations of Great Britain experience in organizing and promoting tourism in various botanic gardens were provided by scientists from Botanic Gardens Conservation International Organization and ArbNet Botanic Garden Organization. The problems of Great Britain experience usage in organizing and promoting tourism in Ukrainian botanic gardens 
were investigated by National Trust Gardens Award, Ukrainian Volunteer Service and also by $\mathrm{UWCF}^{1}$.

Presenting main material. Most botanic gardens in Great Britain have staff responsible for increasing the number of visitors, devising plans and strategies for developing the garden's tourist destination. These people establish relationship with the current client base for travels and develop a tourist destination in the botanic gardens. Their work increases the number of garden visitors and consumers of the tourist services, which naturally stimulates the growth of revenues from tourist activities in the botanic gardens [6].

In carrying out their work, such employees are guided by a number of functional responsibilities (Fig. 1), which can be divided into seven groups as to their application area. This experience is extremely important and relevant for Ukraine. Creating corresponding job positions in the botanic gardens of Ukraine and training appropriate specialists will significantly encourage development of the tourist market in this segment of the tourist destinations.

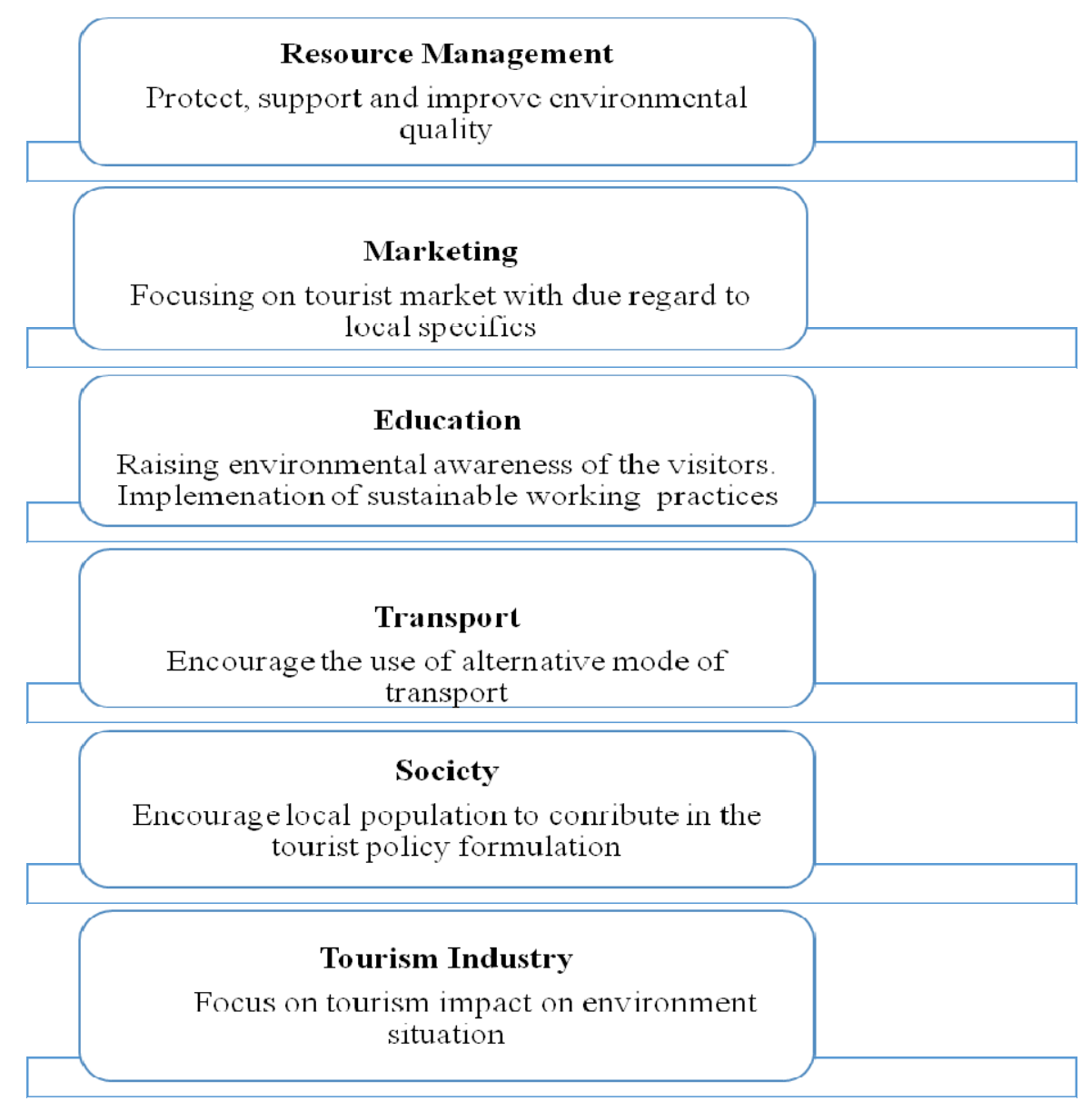

Fig. 1. Main functional responsibilities of the employees in the botanic gardens of Great Britain Source: compiled from [6].

\footnotetext{
${ }^{1}$ UnitedWorldCulturesFoundation.
} 
For successful fulfilment of their functional responsibilities these employees develop a plan for visiting the gardens describing in a detail all priority areas of their promotion in the tourist market, specifying specifics of visits to a botanic garden and its individual location (depending on the season, historical events, specifics of tourist groups), analysing which objects and features in the area are more attractive to tourists and visitors (terrain elements, unique plants, park sculptures etc.). Their functional responsibilities also include maintaining active communication with tour guides, assessing the impact of visitors on the garden environment, working with visitors and tourists individually, communicating and surveying their attitude to the park destination, acquiring new experiences and knowledge etc. Botanic garden employees also need to arrange protection of sensitive information associated with the garden and with tourist destinations within its territory.

The marketing component for tourism development in the botanic gardens of Great Britain is important for analysing the development areas of these tourism destinations. For this purpose, it is necessary to involve the local tourist operators for mutually advantageous cooperation as well as ecological institutions for supervising safe staying of visitors in the garden. It is advisable to maximize the tourist season so that the average annual number of visitors is high, to monitor sources of information for potential visitors about the botanic gardens (advertising booklets, catalogues, posters and websites), and on the basis of such analysis to develop partnership with advertising agencies and other outside organizations (transport, infrastructure, tour operator, excursion, etc.) for promoting relevant tourism products regarding scale, volume, specifics and location.

A botanic garden is a scientific institution in the first place. Therefore, promotion of tourism in its territory should be combined with different types of educational activities, excursions and trips performing the educational function to raise awareness of the population about the environment of the region, unique and endemic plants, animals, insects, including the problems of nature conservation and protection, the use of clean technologies, eco-friendly transport, etc.

Tourism has both positive and negative impact on the natural environment of botanic gardens. Therefore, one of the important aspects of promoting these tourist destinations in Great Britain is to propagate careful attitude to the environment, to disseminate the environmental knowledge among population, to provide ecological consultations to businesses and entrepreneurs on optimizing the environment management system and on making their activities eco-friendly, on developing thematic tourism routes [2].

A public relations program is developed for every botanic garden in Great Britain. It is based on supporting various social initiatives of environmental, ecological, scientific, educational and health (supporting healthy lifestyle) areas. Numerous public tourist forums, social and initiative groups are created in the country 
to propagate a careful attitude to the natural environment and to promote garden and park destinations in the tourism market.

A number of measures are developed and implemented for increasing tourism revenues and helping local businesses linked to the tourism industry in order to create effective strategies for promoting tourism in the botanic gardens of Great Britain. A network of local manufacturers is created to provide the gardens with the necessary tourist products (booklets, guides, souvenirs, etc.), and the network of commercial enterprises, catering, entertainment and recreation facilities is actively developed in the gardens. Volunteers, people of creative professions, artists and designers, animators, landscape planners and others are involved in the promotion of tourist activities in the botanic gardens of Great Britain.

Various organizations involved in development of park and garden eco-tourism assist the botanic gardens of Great Britain in promotion of outdoor tourism. Thus, the organization 'Botanic Gardens Conservation International' in cooperation with ArbNet Botanic Garden developed a partnership program for conservation and development of botanical gardens (Table 1).

Table 1

\section{Partner Program for Conservation and Development of Botanic Gardens}

\begin{tabular}{|l|}
\hline Enhanced cooperation between organizations sharing activities \\
\hline Joint initiatives on plant protection \\
\hline Promotion of sustainable horticulture practices \\
\hline Joint trips for collection \\
\hline $\begin{array}{l}\text { Joint technical experience for implementation of sustainable ecological } \\
\text { practices }\end{array}$ \\
\hline Improved public involvement \\
\hline Improved interpretation programs \\
\hline Development of curricula and training opportunities \\
\hline Improvement of garden management and policy \\
\hline Research of visitors and comparative analysis \\
\hline Marketing and brand development \\
\hline
\end{tabular}

Source: compiled from $[1 ; 2]$.

Partnerships of these two organizations contributed in creation of a foundation for providing grants for implementation of partnership programs on conservation and protection of botanic gardens, rational use of their resources and promotion among tourists and visitors [3].

In addition, the Botanic Gardens Conservation International actively cooperates with other organizations for plant conservation, organization of various educational projects dedicated to plant conservation and regeneration. It has established a public 
relations strategy for conservation and protection of botanic gardens in Great Britain and promotes a more efficient, cost-effective and rational approach to plant conservation in botanic gardens.

The Scottish Government's Environment and Forestry Directorate (ENFOR) is a sponsoring department providing grant support and funding for most of the botanic gardens in Great Britain. As a registered charitable organization it raises funds from trusts and foundations, as well as corporate enterprises focusing on environmental conservation activities and development of numerous cultural and educational programs for nature conservation and protection offered to visitors of the botanic gardens in the country. Moreover, administration of botanic gardens lots upon donations from the public and upon membership contributions from a number of charitable organizations. Investments from environmental organizations, proceeds from educational courses and ecological public events (charity auctions, exhibitions), revenues from publication of various travel guides, albums, booklets and others is another significant source of funds for promotion of tourist activities in the botanic gardens [4].

The National Trust Gardens, association focusing on practical nature preservation, conservation of garden art monuments and beautiful landscapes is actively working in Great Britain. For example, the Trust protects the Bodnant Garden, the winner of the National Trust Gardens Awardin 2013.

The botanic gardens in Great Britain actively encourage various people to become volunteers. For example, volunteers support the Royal Botanic Garden in Edinburgh in many ways and play a key role in forming its positive image among visitors. The main role of a volunteer is to enhance the tourist function of the garden, its cultural and educational value, interest and involvement from visitors. The mission of the volunteers includes explaining the vital role of gardens and individual plants in human daily life and the need to preserve and protect them. Volunteers help organize excursions, exhibitions, cultural events, communication among tourists and visitors to the botanic gardens [5]. For example, the Ness Botanic Gardens at Liverpool University actively attract volunteers regardless of their skills and experiences. For their active work, volunteers receive many bonuses from the garden where they work: they are allowed to attend the Botanic Gardens for free, receive discounts at cafes, shops, free invitations to special events and volunteer parties [7].

Volunteers from the Birmingham Botanic Gardens play a very important role in plant care. This garden always has about 55 volunteers, who regularly visit its various departments and provide extensive assistance in gardening and in organizing cultural, educational, tourist and sightseeing events.

In Ukraine the volunteer movement receives a boost and is continuously developing in the recent years, which is primarily associated with raising the civic awareness of the population. The following powerful volunteer organizations have emerged and are rapidly developing: The Ukrainian Volunteer Service, the volunteer 
programs at the Charitable Foundation UWCF, the UN Volunteer Movement, the Institute for Community Initiatives and others. Unfortunately, initiatives for promotion of tourist activities in the botanic gardens are not active enough. Volunteers from the NGO 'Ukrainian Volunteer Service' should be the driving force in promoting the botanic gardens of Ukraine. For example, every year the Great Wedding Festival is held in the Odessa University Botanic Garden under the auspices of this organization. This festival allows raising funds for the garden regeneration and every spring hundreds of Odessans work for planting rosary and care for the garden territory.

In order to actively promote tourism in the botanic gardens of Ukraine a special volunteer program should be developed. Its main purpose will be to create tourist destinations in the botanic gardens of Ukraine, to form a positive image of gardens among the population and to develop their tourist infrastructure.

The main objectives of the volunteer organizations in promotion of the tourist activity in the botanic gardens of Ukraine include establishing partnership contacts between the botanic gardens; creating a special fund to assist the botanic gardens; developing international cooperation; attracting the state in formulation and implementation of the public policy of assistance to the botanic gardens; developing a number of activities for rational use of nature and environmental protection; determining the priority areas for promotion of botanic gardens in the tourist market; assessing the specifics of visits to the botanic gardens and their individual locations (depending on the season, historical events, features of tourist groups); analysing tourist preferences when visiting botanical gardens (terrain elements, unique plants, park sculptures, etc.); establishing active communication with tour guides; assessing the impact of visitors on the garden environment; individual work with visitors and tourists, communication and surveys regarding their attitude to garden destination, acquiring new experiences and knowledge, etc.; raising awareness among the population about peculiarities of the natural environment in the region and about the problems of nature conservation and protection, the use of eco-friendly technologies, alternative modes of transport and others; promoting the need for a caring attitude to the natural environment, disseminating environmental knowledge among the population, providing environmental advice to businessmen and entrepreneurs, developing thematic green tourism route; developing and implementing measures for increasing tourism revenues and assisting local businesses related to the tourism industry.

Basic methods and activities of the volunteer organizations in promoting tourist activity in the botanic gardens of Ukraine include cooperation with state authorities and public organizations, raising funds and attracting investments, organizing educational courses and environmental public events (charity auctions, auction festivals), animation, publication of various tourist guides, albums, booklets and others, tours in the botanic gardens of Ukraine, creation of their positive image among the population and development of their tourist infrastructure, etc. 
Mobile apps have recently become quite popular way of promoting tourism. The idea of creating a mobile app emerged while surveying the respondents of different age groups about their interest in visiting botanic gardens for tourism purposes. The need to use the mobile app is guided by the desire of potential tourists to learn about current events that will be held in the botanic gardens of a certain area (charity auctions, exhibitions, festivals). The mobile app for promoting tourism in the botanic gardens will include only destinations with active cultural, scientific and educational events. These are the Botanical Garden at the Ivan Franko National University in Lviv, the Odessa Botanical Garden at the Ilia Mechnikov National University, the Aleksandr Fomin Botanical Garden at the Taras Shevchenko National University of Kyiv, the Botanical Garden of the Kharkiv National University of Ukraine, Mykola Gryshko Botanic Garden of the NASU in Kyiv, Kremenets Botanic Garden and others. The apps should include fact-finding information about the botanical gardens of Ukraine and the events to be held in their territory. The app map tools will allow navigating the territory of the botanic garden.

Conclusions. By using the Great Britain experience in promoting tourist activity in botanic gardens Ukraine will contribute in increasing attendance of parks and gardens as tourist destinations of the country, developing their tourist infrastructure, raising awareness of the population about the activities of botanic gardens, implementing nature conservation and ecological programs and arranging effective communication with the public. The Great Britain best practices will assist in preserving and restoring the natural and cultural diversity of the Ukrainian botanic gardens and their active incorporation into the system of tourist services to the population.

\section{REFERENCES}

1. Arbnet Home. - [Electronic resource]. - Source: http://www.arbnet.org

2. Botanic Gardens Conservation International. - [Electronic resource]. Source: http://www.bgci.org/cultivate/article/0410/

3. Global Botanic Garden Fund. - [Electronic resource]. - Source: http://www.bgci.org/joinin/partnerships/

4. Royal Botanic Garden Edinburgh. - [Electronic resource]. - Source: https://www.rbge.org.uk/about-us/organisational-structure/

5. Royal Botanic Garden Edinburgh. - [Electronic resource]. - Source: https://www.rbge.org.uk/support/volunteer/

6. Travel trade sales \& marketing manager, royal botanic garden skew. [Electronic resource]. - Source: https://www.ukinbound.org/tourism-jobs/travel-tradesales-marketing-manager-royal-botanic-gardens-kew

7. University of Liverpool. - [Electronic resource]. - Source: https://www.liverpool.ac.uk/ness-gardens/support-us/volunteering/ 